\title{
PENEGAKAN HUKUM PERSAINGAN USAHA DALAM PENERAPAN ALAT BUKTI TIDAK LANGSUNG (INDIRECT EVIDENCE) TERHADAP PRAKTIK KARTEL
}

\author{
Dimas Surya Pranata \\ E-mail: dimassuryap24@gmail.com \\ Mahasiswa Fakultas Hukum Universitas Sebelas Maret \\ Hernawan Hadi \\ E-mail: hernawanhadi@gmail.com \\ Dosen Fakultas Hukum Universitas Sebelas Maret
}

\begin{abstract}
This article aims to know the enforcement of business competition law in the implementation of indirect evidence on cartel practices. This article belongs to legal principles and legal doctrines in order to answer the legal problems encountered who based focus read and study materials primary and secondary law. For law drafting to be able to produce arguments for new theories or concepts, it is a prescription for solving the problems of this legal research. The results of the research indicate that the enforcement of business competition law against cartel practices in Indonesia continues to face obstacles and has not been maximized. This indirect evidence can be used as a solution to the difficulty of proving the practice of cartels in business competition laws, provided that they are equipped with other evidence. Indirect evidence may be included in the category of evidence in Article 42 of Law No. 5 of 1999 on Prohibition of Monopoly Practices and Unfair Competition.
\end{abstract}

Keywords: Law Enforcement; Indirect evidence; Cartel Practices

\begin{abstract}
Abstrak
Artikel ini bertujuan untuk mengetahui penegakan hukum persaingan usaha terhadap penerapan alat bukti tidak langsung (indirect evidence) terhadap praktik kartel. Artikel ini merupakan penelitian hukum doktrinal atau normatif yaitu suatu proses untuk menemukan aturan hukum, prinsip-prinsip hukum, maupun doktin-doktrin hukum guna menjawab isu hukum yang dihadapi yang dilakukan dengan cara meneliti bahan pustaka (library based) yang berfokus pada membaca dan mempelajari bahan-bahan hukum primer dan sekunder. Sehingga penulisan hukum mampu menghasilkan argumentasi teori atau konsep baru sebagai preskripsi dalam menyelesaikan masalah yang terkait dalam penelitian hukum ini. Hasil Penelitian menyatakan penegakan hukum persaingan usaha terhadap praktik kartel di Indonesia masih menemui kendala dan belum maksimal. Alat bukti tidak langsung (indirect evidence) ini dapat dijadikan solusi atas sulitnya pembuktikan praktik kartel dalam hukum persaingan usaha, Alat bukti tidak langsung (indirect evidence) dapat dimasukkan dalam kategori alat bukti sebagaimana yang dimaksud dalam ketentuan Pasal 42 Undang-Undang Nomor 5 Tahun 1999 tentang Larangan Praktik Monopoli dan Persaingan Usaha Tidak Sehat.
\end{abstract}

Kata Kunci: Penegakan Hukum; Indirect evidence; Praktik Kartel

\section{A. Pendahuluan}

Perkembangan sistem perekonomian Indonesia saat ini menjadikan persaingan usaha sebagai salah satu instrumen ekonomi sejak saat reformasi digulirkan. Hal ini ditunjukan melalui diundangkannya Undang-Undang Nomor 5 Tahun 1999 tentang Larangan Praktek Monopoli dan Persaingan Usaha Tidak Sehat. Undang-Undang Nomor 5 Tahun 1999 tentang Larangan Praktek Monopoli dan Persaingan Usaha Tidak Sehat merupakan tonggak bagi diakuinya persaingan usaha yang sehat sebagai pilar ekonomi dalam sistem perekonomian Indonesia berdasarkan Pancasila dan Undang-Undang Negara Republik Indonesia Tahun 1945. Kelahiran Undang-Undang 
Nomor 5 Tahun 1999 tentang Larangan Praktek Monopoli dan Persaingan Usaha Tidak Sehat juga merupakan koreksi terhadap perkembangan ekonomi yang memprihatinkan, yang terbukti tidak tahan terhadap goncangan krisis pada tahun 1997. Undang-Undang Nomor 5 Tahun 1999 tentang Larangan Praktek Monopoli dan Persaingan Usaha Tidak Sehat kini menjadi instrumen penting dalam penegakan hukum di dalam pasar ekonomi. (Andi Fahmi Lubis, et al., 2009: 10).

Persoalan yang begitu komplek dalam penegakan hukum larangan praktik monopoli dan persaingan usaha tidak sehat telah berimplikasi pada keefektifan pelaksanaan tugas dan kewenangan yang diamanatkan oleh undang-undang. Pembuktian dalam perkara kartel bukanlah hal yang mudah, sulitnya menemukan alat bukti yang dapat digunakan dalam persidangan membuat pembuktian dalam perkara kartel menjadi berbeda dengan pembuktian lainnya. Para pelaku kartel sebisa mungkin menghindari penggunaan perjanjian secara tertulis agar kegiatan mereka sulit untuk dibuktikan. Para pelaku kartel dapat dipastikan akan selalu berusaha bagaimana agar rahasia atau kesepakatan yang mereka buat jangan sampai jatuh ke tangan KPPU. Untuk itu para pelaku kartel tidak akan ragu untuk menutup rapat-rapat terhadap pihak yang mereka anggap berpotensi menggangu kesepakatan yang telah mereka buat (Binoto Nadapdap, 2019:5).

Permasalahan yang dihadapi adalah bagaimana penegakan hukum persaingan usaha dalam penerapan alat bukti tidak langsung (indirect evidence) terhadap praktik kartel. Tujuan penelitian adalah meninjau dan mengetahui bagaimana penegakan hukum persaingan usaha terhadap penerapan alat bukti tidak langsung (indirect evidence) terhadap praktik kartel. Penelitian ini akan bermanfaat bagi pelaku usaha maupun lembaga otoritas persaingan usaha untuk memberikan jawaban atas sulitnya penanganan praktik kartel serta memberikan pandangan mengenai penegakan hukum persaingan usaha dalam penggunaan alat bukti tidak langsung (indirect evidence)

Dalam artikel ini penulis akan membahas mengenai bagaimana penegak hukum persaingan usaha dalam penggunaan alat bukti tidak langsung (indirect evidence) terhadap praktik kartel.

\section{B. Metode Penelitian}

Artikel ini termasuk ke dalam jenis penelitian hukum normatif. Sifat penelitian yang digunakan yaitu penelitian preskriptif untuk menghasilkan konsep baru dalam menyelesaikan permasalahan yang dihadapi (Peter Mahmud Marzuki, 2015:69). Pendekatan penelitian yang akan digunakan dalam penelitian ini adalah pendekatan undang-undang (statue approach) dan pendekatan kasus (case approach) (Peter Mahmud Marzuki, 2015:24). Jenis data yang akan digunakan penulis dalam penelitian ini adalah data sekunder, yaitu data yang diperoleh melalui pengkajian pustakapustaka yang ada dalam hal ini bahan hukum sekunder adalah jurnal-jurnal, buku-buku dan doktrin dari para ahli mengenai sebuah analisis, Serta Bahan Hukum Primer sebagai bahan hukum yang sifatnya mengikat dan mendasar. Teknik pengumpulan bahan hukum yang akan digunakan dalam penelitian hukum ini adalah studi dokumen atau studi kepustakaan (library research).

\section{Hasil Penelitian dan Pembahasan}

Sherman Act bagian satu menyebutkan bahwa:

Every contract, combination in the form of trust or otherwise, or conspiracy, in restraint of trade or commerce among the several States, or with foreign nations, is declared to be illegal. Every person who shall make any contract or engage in any combination or conspiracy hereby declared to be illegal shall be deemed guilty of a felony, and, on conviction thereof, shall be punished by fine not exceeding $\$ 10,000,000$ if a corporation, or, if any other person, $\$ 350,000$, or by imprisonment not exceeding three years, or by both said punishments, in the discretion of the court (The Sherman Antitrust Act, 1980:1).

(Terjemahan bebas: Setiap kontrak, baik gabungan atas dasar kepercayaan ataupun sebaliknya, atau persekongkolan dalam menahan perdagangan antar beberapa negara, atau dengan negara-negara asing dinyatakan ilegal. Setiap orang yang akan membuat kontrak atau terlibat dalam gabungan atau persekongkolan ini dinyatakan ilegal dan akan dianggap bersalah 
karena melakukan kejahatan. Jika yang melakukan sebuah perusahaan dan terbukti bersalah maka akan dikenakan denda paling banyak sebesar $\$ 10.000 .000$ atau, jika yang melakukan adalah perorangan maka akan dikenakan denda paling banyak sebesar $\$ 350.000$, atau dipenjara paling lama tiga tahun, atau dengan kedua hukuman tersebut, sesuai putusan pengadilan).

Pengertian kartel di Indonesia terdapat dalam Pasal 11 Undang-Undang Nomor 5 Tahun 1999 tentang Larangan Praktik Monopoli dan Persaingan Usaha Tidak Sehat yang pada dasarnya adalah perjanjian satu pelaku usaha dengan pelaku usaha pesaingnya untuk menghilangkan persaingan di antara keduanya. Secara klasik kartel dapat dilakukan melalui tiga hal yaitu harga, produksi, dan wilayah pemasaran. Dalam pengertian tersebut terdapat beberapa unsur, salah satunya adalah perjanjian. Perjanjian antar pelaku usaha yang tergabung dalam kartel menjadi salah satu alat bukti yang dapat digunakan untuk membantu proses pembuktian dalam praktik kartel.

Kerahasiaan yang dijaga oleh para pelaku kartel menjadi kesulitan yang lebih bagi KPPU untuk mendapatkan alat bukti dalam praktik kartel. Alat bukti yang sangat sulit didatangkan tetapi memiliki peran penting dalam pembuktian praktik kartel adalah alat bukti langsung yang menunjukkan adanya kerjasama antar pelaku usaha untuk melakukan kartel. Alat bukti langsung yang dimaksudkan adalah dokumen, ataupun surat yang secara tertulis menyatakan sebuah perjanjian kartel. Perjanjian secara tertulis dalam bentuk dokumen atau surat sangat dihindari oleh pelaku usaha di dalam melakukan kartel. Sehingga Komisi cukup kesulitan dalam mendatangkan alat bukti langsung berupa perjanjian kesepakatan antar pelaku usaha. Oleh sebab sulitnya penemuan alat bukti guna pembuktian kartel, maka KPPU menggunakan alat bukti tidak langsung (indirect evidence) sebagai solusi untuk menangani praktik kartel. Salah satu alat bukti yang termasuk adalah indirect evidence adalah melalui analisis ekonomi.

Penggunaan analisis ekonomi dalam kartel adalah studi atau metodologi ekonomi guna mendukung identifikasi faktor-faktor yang dapat diindikasikan sebagai kolusif atau pasar-pasar yang memfasilitasi terbentuknya perilaku yang kolusif. Secara umum analisis ekonomi dapat dibagi menjadi dua metodologi, yakni pendekatan struktural (structural approach) dan pendekatan perilaku (behavioural approach). Pendekatan struktural meliputi identifikasi pasar dengan karakteristik yang kondusif untuk melakukan tindakan kolusif. Dalam beberapa studi atau literatur ekonomi dapat diidentifikasikan beberapa faktor terkait dengan struktur pasar dan kekuatan pasar yang mendorong atau memfasilitasi terbentuknya perilaku kartel. Faktor-faktor ini dapat dijadikan sebagai indikasi terbentuknya suatu kartel. Sebagai contoh misalnya terbentuknya kartel dalam suatu pasar akan mudah terjadi jika pasar terdiri atas beberapa pelaku usaha, dengan produk yang homogen, dan permintaan (demand) yang stabil. Pendekatan lain adalah pendekatan perilaku, yang lebih menekankan pada sebuah output berupa adanya kemungkinan tindakan koordinatif antar pelaku kartel. Pendekatan ini berfokus pada dampak terhadap pasar atas koordinasi tersebut. Hal-hal yang perlu dicurigai antara lain adalah harga, diskon yang sama atau identik di antara pesaing, pergerakan harga yang paralel atau kenaikan harga yang unjustified atau unexplained, atau pemasok yang berbeda menaikkan harga dengan margin yang sama dalam waktu yang bersamaan. Namun demikian, kadangkala peningkatan harga secara paralel merupakan petunjuk adanya pasar yang bersaing secara ketat (Anna Maria Tri Anggraini, 2010: 37-38).

Alat bukti tidak langsung (indirect evidence) hanya dapat diterapkan dengan disertai penjelasan logis dengan metode analisis yang dapat diterima secara keilmuan terutama ilmu ekonomi. Analisis terhadap alat bukti tidak langsung (indirect evidence) menghasilkan indikasi-indikasi yang meyakinkan bahwa telah terjadi suatu perbuatan anti persaingan dan siapa pelakunya. Oleh karena itulah, tidak semua orang dapat menerima penerapan bukti tidak langsung tersebut. Selain karena memerlukan pemahaman yang spesifik terhadap aspek ekonomi dan karena bukti tersebut tidak secara langsung dapat menunjukkan terjadinya peristiwa atau perbuatan anti persaingan yang disangkakan. Selain itu salah satu kekurangan yang ada pada undang-undang Nomor 5 Tahun 1999 tentang Larangan Praktik Monopoli dan Persaingan Usaha Tidak Sehat sendiri adalah belum diatur secara jelas hukum acara yang digunakan dalam Undang-Undang Nomor 5 Tahun 1999 
tentang Larangan Praktek Monopoli dan Persaingan Usaha Tidak sehat untuk penanganan perkara di KPPU. Di Indonesia ada sejumlah peraturan perundang-undangan yang mengatur tentang alat bukti. Dari sejumlah undang-undang yang mengatur alat bukti, tidak ada yang secara khusus mengatur mengenai alat bukti langsung dan alat bukti tidak langsung. Undang-undang hanya mengatur mengenai macam-macam alat bukti secara limitatif dan enumeratif (Binoto Nadapdap, 2019:195-197).

Undang-Undang Nomor 5 Tahun 1999 tentang Larangan Praktik Monopoli dan Persaingan Usaha Tidak Sehat tidak menjelaskan sistem pembuktian yang dianut dalam menegakkan undangundang tersebut. Pasal 42 Undang-Undang Nomor 5 Tahun 1999 tentang Larangan Praktek Monopoli dan Persaingan Usaha Tidak Sehat tersebut hanya menyebutkan tentang alat bukti yang dipergunakan oleh Majelis dalam memutus perkara dugaan pelanggaraan terhadap undangundang. Keadaan ini menimbulkan perbedaan pendapat mengenai apakah Majelis Komisi wajib membuktikan hanya menggunakan jenis alat bukti yang tercantum dalam Pasal 42 Undang-Undang Nomor 5 Tahun 1999 tentang Larangan Praktek Monopoli dan Persaingan Usaha Tidak Sehat saja atau dapat menggunakan alat bukti lain. Perdebatan juga terjadi dalam kaitannya dengan jumlah alat bukti minimum yang dipergunakan oleh Majelis Komisi dalam memutuskan sebuah perkara. Jika dalam KUHAP secara tegas disebutkan bahwa majelis hakim dalam memutuskan perkara menggunakan sekurang-kurangnya 2 (dua) alat bukti ditambah dengan keyakinan hakim, maka dalam Undang-Undang Nomor 5 Tahun 1999 tentang Larangan Praktik Monopoli dan Persaingan Usaha Tidak Sehat tidak disebutkan secara jelas norma yang demikian (Mahmul Siregar, 2018:193).

Meskipun alat bukti tidak langsung (indirect evidence) tidak disebutkan secara eksplisit dalam Pasal 42 Undang-Undang Nomor 5 Tahun 1999 tentang Larangan Praktek Monopoli dan Persaingan Usaha Tidak Sehat, tidak berarti bahwa bukti tidak langsung tersebut sama sekali tidak bersentuhan dengan jenis alat bukti sebagaimana disebutkan dalam Pasal 42 Undang-Undang Nomor 5 Tahun 1999 tentang Larangan Praktek Monopoli dan Persaingan Usaha Tidak Sehat tersebut. Satu jenis alat bukti dalam Pasal 42 Undang-Undang Nomor 5 Tahun 1999 tentang Larangan Praktek Monopoli dan Persaingan Usaha Tidak Sehat yang berkaitan dengan penggunaan bukti tidak langsung adalah bukti petunjuk. Undang-Undang Nomor 5 Tahun 1999 tentang Larangan Praktek Monopoli dan Persaingan Usaha Tidak Sehat tidak menjelaskan lebih lanjut apa yang dimaksud dengan bukti petunjuk. Alat bukti petunjuk merupakan pengetahuan Majelis Komisi yang olehnya diketahui dan diyakini kebenarannya. Pengertian alat bukti petunjuk dalam Peraturan Komisi ini lebih luas dibandingkan dengan bukti petunjuk sebagaimana dikenal secara umum dalam hukum acara pidana.

Berdasarkan Policy Brief June 2007, Prosecuting Cartels without Direct Evidence of Agreement yang dikeluarkan oleh OECD bukti tidak langsung adalah bukti yang tidak secara langsung menggambarkan isi dari perjanjian atau para pihak dalam perjanjian tersebut. Bukti tidak langsung terdiri dari bukti komunikasi antar para pelaku usaha yang dicurigai melakukan kartel dan bukti ekonomi tentang pasar serta perilaku dari para pelaku usaha kartel yang terlibat di dalamnya yang mengusulkan tindakan bersama tersebut. Dengan demikian bukti tidak langsung adalah merupakan alat untuk mendeteksi bahwa ada indikasi praktik kartel yang dilakukan oleh para pelaku usaha, yaitu berupa perjanjian antara pelaku usaha yang menetapkan harga jual barang atau jasa tertentu kepada konsumen (Mahmul Siregar, 2018:192).

Alat bukti tidak langsung (indirect evidence) sebenarnya telah digunakan di beberapa negara. Alasan yang sama untuk mendasari penerapan alat bukti tidak langsung (indirect evidence) adalah pembuktian kartel tekait menemukan adanya kesepakatan antara pelaku kartel sebagai alat bukti yang teramat susah sehingga perlu menggunakan alat bukti yang mampu menjadi solusi atas permasalahan pembuktian, sehingga praktik kartel dapat dihentikan dan tidak menimbulkan kerugian bagi pelaku usaha, konsumen, serta negara. Beberapa negara yang telah menerapkan alat bukti tidak langsung (indirect evidence) antara lain (Binoto Nadapdap, 2019:251): 
1. Amerika Serikat

Acuan tambahan seperti plus faktor ataupun facilitating devices ditambahkan untuk memperjelas bukti bahwa telah terjadi pelanggaran terhadap undang-undang Anti-trust. Plus faktor yang sering ditekankan oleh pengadilan apakah tindakan dari perusahaan tersebut bertentangan dengan kepentingan sendiri (against self interest), plus faktor merupakan faktor penentu yang dibutuhkan untuk memperkuat keyakinan akan bukti ekonomi sebagai bagian dari indirect evidence dimana tidak terdapat perjanjian yang tertulis (naked agreement). Penegakan mengenai faktor ekonomi yang menantang penggunaan fasilitas pendukung sebagai cara untuk memberi tanda harga dan koordinasi harga di antara perusahaan oligopolis.

2. Jepang

Formula yang tepat untuk dapat mempergunakan alat bukti tidak langsung dalam penanganan praktik kartel adalah adanya komunikasi ditambah dengan kesamaan perilaku. Komunikasi dan kesamaan perilaku itu sendiri bukan merupakan alat bukti langsung tetapi merupakan alat bukti tidak langsung. Dengan singkat dapat dikatakan bahwa untuk dapat mempergunakan alat bukti tidak langsung dalam penanganan kartel paling tidak harus ada dua alat bukti tidak langsung, sekalipun tanpa dibarengi dengan alat bukti langsung.

3. Uni Eropa

Tidak ada pengaturan yang jelas mengenai alat bukti apa yang dapat dipergunakan oleh komisi persaingan dalam menangani perkara pelanggaran terhadap hukum anti-monopoli. Kepada komisi diberikan kewenangan untuk menentukan sendiri alat bukti apa yang mereka pergunakan. Pembuktian dapat dilakukan dengan menggunakan semua alat bukti. Komisi mempunyai kebebasan untuk memilih alat bukti dan tidak ada daftar yang lengkap mengenai alat bukti tidak langsung.

Alat bukti tidak langsung (indirect evidence) merupakan suatu fakta yang bukan menjadi satusatunya fakta yang berkaitan dengan suatu perkara, namun fakta tersebut berasal dari fakta-fakta yang berkaitan ataupun tidak dengan kasus tersebut, yang kemudian dapat diambil kesimpulan. Kesimpulan dimaksud terkait dengan terjadinya suatu peristiwa atau perbuatan hukum tertentu. Selanjutnya Munir Fuady menyebutkan bahwa alat bukti tidak langsung (indirect evidence) haruslah memiliki relevansi yang rasional yang dapat menunjukkan bahwa penerapan alat bukti tidak langsung (indirect evidence) tersebut dalam proses pengadilan, lebih besar kemungkinan dapat membuat fakta yang dibuktikan tersebut menjadi lebih jelas dari pada jika tidak digunakan alat bukti tidak langsung (indirect evidence) (Munir Fuady, 2012:5).

Di Indonesia sendiri meskipun penerapan alat bukti tidak langsung (indirect evidence) masih menjadi perdebatan, tetapi Mahkamah Agung sudah pernah memutus perkara yang memenangkan KPPU dalam penerapan alat bukti tidak langsung (indirect evidence) atas Putusan Pengadilan Negeri Jakarta Barat yang membatalkan Putusan KPPU Nomor 02/KPPU-L/2009 Tentang Perkara Tender Paket Pekerjaan Pembangunan Jaringan Air Bersih Kabupaten Lingga. Kemudian KPPU mengajukan upaya hukum kasasi kepada Mahkamah Agung. Permohonan kasasi dari KPPU ini dikabulkan oleh Mahkamah Agung melalui putusannya dalam Perkara Nomor 582K/Pdt.Sus/2009 tanggal 28 September 2009 (Binoto Nadapdap, 2019:377).

Sulitnya pembuktian adanya kartel dan dengan keterbatasan waktu yang dimiliki oleh KPPU dalam mengungkap dugaan kartel serta adanya pro dan kontra dalam praktik, maka sering kali menimbulkan permasalahan. Maka untuk menghindari dan memberikan kepastian hukum bagi semua pihak, perlu adanya amandemen terhadap Undang-Undang Nomor 5 Tahun 1999 tentang Larangan Praktek Monopoli dan Persaingan Usaha Tidak Sehat dengan memasukan alat bukti tidak langsung (indirect evidence) ke dalam jenis alat bukti yang diatur secara jelas dalam Pasal 42 terkait alat bukti yang sah. Kemudian, diperlukan penguatan terhadap kewenangan KPPU yang diatur secara jelas dalam Pasal 36 dengan menambahkan wewenang untuk melakukan penggeledahan ataupun penyitaan, diberikannya hak sadap bagi KPPU serta penambahan jangka waktu dalam penanganan kartel (Sukarmi, 2011:144). 


\section{Simpulan}

Penegakan hukum persaingan usaha terhadap praktik kartel di Indonesia masih menemui kendala dan belum maksimal. Penerapan alat bukti tidak langsung (indirect evidence) masih menemui pro dan kontra karena belum adanya peraturan perundang-undangan yang mengatur secara jelas mengenai jenis alat bukti tersebut. Meskipun pengaturan mengenai alat bukti tidak langsung (indirect evidence) belum jelas, tetapi Mahkamah Agung sudah pernah menguatkan putusan KPPU dalam penerapan alat bukti tidak langsung (indirect evidence) terhadap perkara kartel. Alat bukti tidak langsung (indirect evidence) dapat menjadi pembaruan dan solusi atas sulitnya penegakan hukum persaingan usaha terhadap praktik kartel. Sulitnya mendapatkan alat bukti langsung berupa kesepakatan antara pelaku kartel memerlukan sebuah pembaruan dan terobosan dengan melakukan amandemen terhadap Undang-Undang Nomor 5 Tahun 1999 tentang Larangan Praktek Monopoli dan Persaingan Usaha Tidak Sehat. Amandemen yang dimaksudkan adalah dengan menambahkan alat bukti tidak langsung (indirect evidence) kedalam Pasal 42 mengenai jenis alat bukti yang sah. Selain itu pemberian kewenangan tambahan kepada KPPU untuk melakukan penyitaan dan penggeledahan dirasa perlu untuk mempermudah KPPU dalam menangani perkara kartel, kemudian apabila dirasa pas dan memang diperlukan dapat menambahkan peraturan mengenai adanya kekebalan hukum atau keringanan hukum, kepada perorangan, karyawan perusahaan, maupun perusahaan yang pertama memberikan keterangan atau informasi terkait dengan praktek kartel atau disebut dengan leniency program.

\section{E. Saran}

Pertimbangan hukum Mahkamah Agung yang menerima alat bukti tidak langsung (indirect evidence) sebagai alat bukti yang sah dalam hukum persaingan usaha dapat menjadi terobosan hukum dalam penegakan hukum persaingan usaha di Indonesia, baik bagi KPPU maupun Pengadilan Negeri. Apabila alat bukti tidak langsung (indirect evidence) ingin diterima sebagai alat bukti yang sah tanpa menimbulkan perbedaan pandangan, maka perlu diatur kedudukannya sebagai jenis alat bukti yang sah dalam Pasal 42 Undang-Undang Nomor 5 Tahun 1999 tentang Larangan Praktik Monopoli dan Persaingan Usaha Tidak Sehat. Penambahan kewenangan bagi KPPU terkait penggeledahan dan penyitaan harus ditambahkan dan diatur karena dengan begitu KPPU dapat dengan lebih mudah mendapatkan bukti langsung berupa dokumen yang mengindikasikan terjadinya perjanjian kartel. Leniency program sebaiknya dipertimbangkan untuk diatur dalam Undang-Undang Nomor 5 Tahun 1999 tentang Larangan Praktik Monopoli dan Persaingan Usaha Tidak Sehat, mengingat banyak negara lain sudah menerapkan dan memberikan hasil yang efektif dalam kemudahan untuk menangani praktik kartel. Oleh karena itu, sebaiknya Dewan Perwakilan Rakyat Republik Indonesia melakukan amandemen terhadap Undang-Undang Nomor 5 Tahun 1999 tentang Larangan Praktek Monopoli dan Persaingan Usaha Tidak Sehat mengingat perlunya langkah tersebut untuk dilakukan.

\section{F. Daftar Pustaka}

Andi Fahmi Lubis, et al. 2009. Hukum Persaingan Usaha Teks dan Konteks. Jakarta: Komisi Pengawas Persaingan Usaha.

Binoto Nadapdap. 2019. Hukum Persaingan Usaha Bukti Tidak Langsung (Indirect Evidence) Versus Tembok Kartel. Jakarta: Jala Permata Aksara.

Munir Fuady. 2012. Teori Hukum Pembuktian Pidana dan Perdata. Bandung: Citra Aditya Bakti.

Peter Mahmud Marzuki. 2015. Penelitian hukum. Jakarta: Kencana Prenanda Media Group.

Anna Maria Tri Anggraini. 2010. "Penggunaan Analisis Ekonomi dalam Mendeteksi Kartel Berdasarkan Hukum Persaingan Usaha". Jurnal Persaingan Usaha. Volume 4. Nomor 3. Jakarta: Komisi Pengawas Persaingan Usaha. 
Mahmul Siregar. 2018. "Bukti Tidak Langsung (Indirect evidence) dalam Penegakan Hukum Persaingan Usaha di Indonesia". Samudra Keadilan. Volume 13. Nomor 2. Medan:. Fakultas Hukum Universitas Sumatera Utara.

Sukarmi. 2011. "Pembuktian Kartel dalam Hukum Persaingan Usaha. Edisi 6 Tahun 2011. Jurnal Persaingan Usaha. Volume 6. Nomor 6. Jakarta: Komisi Pengawas Persaingan Usaha.

Undang-Undang Nomor 5 Tahun 1999 tentang Larangan Praktek Monopoli dan Persaingan Usaha Tidak Sehat

The Sherman Antitrust act 1890 